\title{
THE PRACTICE OF TEACHING READING SKILLS: PREPARATORY SCHOOL IN FOCUS
}

\author{
Alebel Adego Abebe \\ MA/Lecturer in Teaching English as a Foreign Language, \\ Department of English Language and Literature, University of Gondar, Ethiopia
}

DOI: $10.37648 / \mathrm{ijrssh} . v 10 \mathrm{i} 02.004$

Received:07 ${ }^{\text {th }}$ December, 2019; Accepted:04 ${ }^{\text {th }}$ January, 2020; Published: $30^{\text {th }}$ January, 2020

\begin{abstract}
The study was conductedto assess the practice of teaching reading skill of grade twelve at Fasiledes Preparatory School.Out of 910 students and 10 English teachers, six teachers and three hundred fourteen students were selected using simple randomsampling technique, lottery method in particular. The head of the departmentwho workedas a supervisorwas chosen purposively. The data were collected through questionnaire,interview and classroom observations. Fourteen closed ended questions consisting of Likert Scale type were administered to students and these items were again used for observation checklist. Each teacher was observed four times with a total oftwenty four observations and triangulated with students' response and interview result of the supervisor. The data were discussed quantitatively and qualitatively. The data obtained from questionnaire of students was analyzed using percentages and mean values with the integration of observation results which was analyzed using percentages. The finding in thepre reading stagewith grand mean 2.2 which is less than the expected mean 3 indicated that teachers rarely implemented this stage. The mean values 2.9 and 2.3 of respondents showed thatteachers practiced sometimes and rarely to while and postreading stages respectively. These results are also supported by the findings gained from interview and classroom observations. Generally, most teachers do not teach the three reading stages properly. Therefore, teachers should be given on job training about teaching readingskill. School supervisors should observe the practice of reading in the classroom and assist teachers so that there will be a better teaching learning process.
\end{abstract}

Keywords: practice, pre-reading, while-reading, post-reading

\section{INTRODUCTION}

English is given as a subject beginning from grade one and a medium of instruction in high schools and higher institutions of learning in the Ethiopian curriculum. It also serves as the language of science, technology and the media in many parts of the world. Moreover, it helps learners to communicate in the classroom and in a wide variety of everyday life situations.

Wendy and Scoths (1994) explained that a very important way of helping students to work responsibly and independently is to give them the necessary tools. One of the tools is classroom language. When we learn a language, there are four language skills that we need for complete communication. We usually learn to listen first, then to speak, then to read, and finally to write.

Therefore, inorder to teach these four language skills effectively, teachers need to apply clearly designed teaching methods to assist students use the target language. However, there are teachers who do not teach and follow the suggested teaching techniques and procedures. Forexample,Nunan(1988) showed that there is a mismatch between the planned activities and the actual implementation in the classroom.Likewise, Breen (1989) indicatedthat designingteachingmaterialsalonedoes not mean 
(IJRSSH) 2020, Vol. No. 10, Issue No. II, Apr-Jun

the achievement of the objectives unless it is implemented in the classroom using suitable methodology. From this, we can understand that applying effective classroom methodology in teaching a language has a positive impact on the students' performance. Thus,likeotherskills, teaching readingneedscarefullyselected teaching methodologyat allgrade levels.

Therefore, this study focusesoninvestigating thepractices ofteachingreadingatpreparatory school levelongrade12 at Fasiledes Preparatory School in Gondar city administration.

\section{STATEMENT OF THE PROBLEM}

The ultimate goal of teaching the English language is to enable the learners to use the target language and communicate their opinions, thoughts and feelings (Krashen\& Terrell, 1983).For a communication to take place successfully, it is important that the learner listen, speak, read and write in the language. Readingis one of the mostimportantskills to be practiced fromthe primary to the university levels. Related to this Khan(2004)showed that reading is one of the most important language skill in receiving information from the written materials. It is also used to understand the subject matter in every field of study. Reading is the most important skill in Ethiopia where English is used as a foreign language.

Devine(1981) shows that in spite of the availability ofaudiovisual devices, reading continues to be the major way of learning today to get information, enhance concepts,and motivating ideas. Getachew(1996)shows that reading is the most important among the four language skills. Related to this Atkins, J. Hailom\&Nuru (1996:39)states that "almost all the examinations which test their knowledge and abilities are based on their reading and comprehending abilities in English.In addition to the need for efficient reading for academic purposes,acquiring this skill is increasingly important for practical purposes in the real world after school."
e-ISSN: 2249-4642, p-ISSN: 2454-4671

However, according to Atkins et al.(1996) many high school students are weak in their reading ability in English Language. This weakness affects their studies and academic performance.The major factors affecting students reading are ineffective teaching of reading and inappropriate tasks to help students enhance their reading abilities.Therefore,for the advantage of next generation, it is important to enhance the teaching of reading in the Ethiopian high schools.

Kukukoglu(2012) conducted action research on how to improve the reading comprehension of students in Turkey. The study aimed on the effective reading strategies so as to improve the reading skill of students in the classroom. Studentshad a very low awareness aboutreadingstrategiesat thebeginningofthestudy. The researcher finally found that teaching reading strategies is most important in order to improve the students comprehension. Therefore,the research showed that if teachers implement the appropriate strategies or methods, the comprehension of students will be enhanced. Similarly, Albdour(2015)conducted a research on the difficulties affecting the grade seven students reading comprehension. The study showed that students had a high degree of reading comprehension problems and recommended that trainings on teaching reading skill should be given.

There are related local studies in this area. For example,Paulos(2015)conducted a research on the reading activities of grade eleven.The study focused on how the reading activities or tasks are designed , and how these activities are distributed in the text book. The finding of the study revealed that readingfordetails,mainideas, wordattackskills,information transferskills andpredictingskill were includedbelow average. Other activities like skimming,, references and relating to their own idea, designed in moderate ways. On the other hand, scanning activities and inferences appeared more than average. Dereje (2008) also made a research on identifying tasks 
(IJRSSH) 2020, Vol. No. 10, Issue No. II, Apr-Jun

that require considerations in preparing and applying motivational techniques in reading lessons. The research focused on assessing students perception on the frequency of teachers motivational techniques, students opinion on reading materials and teachers pedagogical presentation related to reading skill. The research showed that most students perceived additional materials as essential to them. Nevertheless, teachers sometimes use these materials. More than half percent of the students believed that participating in classroom discussions encourages them in reading lessons.Mesfin (2008) did a research on how grade four students and teachers practice reading skill. The researcher also investigated the students reading ability in the aforementioned grade level. The result depicted that students practiced inappropriate reading techniques and procedures. Likewise, teachers used traditional method of teaching reading, and practiced almost no silent reading. This study is different from the aforementioned researches in many ways. For example, Paulos(2015) focuses on how the reading activities or tasks are designed and distributed in the text book and Dereje (2008)studied in preparing and applying motivational techniques in reading lessons. In order to teach reading skill effectively, there are important stages that the teacher should follow. These procedures include pre, while and post readings (Atkins et al., 1996). To the best of my knowledge, I can't get a research done on how the teachers implement reading stages. i.e how teachers practice the pre-reading,the while-reading and post reading stages have not yet been touched.

I have been teaching the communicative English skills to the first year students at the University of Gondar for six years. Fromclassroomobservations and assessments I have carriedout as partof myprofessional activity, the majority of the students' reading skill result is below the standard or expected.In addition, informal and formal departmental discussions indicated that many first year students are weak in their reading comprehension. These students, even, are unable to answer very simple comprehension questions. Ontop ofthis, there are complaints from the
e-ISSN: 2249-4642, p-ISSN: 2454-4671

students themselves that teachers do not teach reading skill properly in the preparatory schools.

Therefore, the researcher is inspired to assess on how the reading skill is taught in grade twelve of FasiledesPreparatory School. Therefore, the researcher formulated the following research questions.

1. How do teachers teach the pre-reading skill in the classroom?

2. How do teachers teach the while-reading skill in the classroom?

3. How do teachers teach the post-reading skill in the classroom?

\section{METHODOLOGY OF THE STUDY}

\section{Design of the Study}

This study employeddescriptive design using quantitative and qualitative data analysis method to assess how teachers teach reading skill.

\section{Population, Sample and Sampling Methods}

The study was conducted in Gondarcity Fasiledes preparatory School which was selected randomly among five schools has two grade levels: grades eleven and twelve. The researcher again randomly selected grade twelve. This was because all of the teachers teach both grade eleven and twelve. There were fourteen sections of grade twelve with a total number of 910 students, on average, 65 students in each section and $314(34.5 \%)$ of the students were taken as a sample. These students were selected using simple random sampling, specifically, the lottery method. This method was used because the population has similar characteristics and has an equal chance to be selected. The reason why the researcher included samples from each section was that there was a possibility that students in each section were taught by different teachers with different teaching experience.There were ten English language teachers in the school. Six $(66.7 \%)$ of the teachers were selected for the study using lottery method. The head of the English language department was selected purposely for interview because the head was worked as a supervisor in the 
(IJRSSH) 2020, Vol. No. 10, Issue No. II, Apr-Jun

school and could provide information about the reading practices in the classroom.

\section{DATA COLLECTION INSTRUMENTS}

In this study questionnaire, interview and classroom observations were used as data collecting tools.

\section{Questionnaire}

To collect data from students close ended questions were prepared. Fourteen close ended questions with five scoring of Likert Scale ranging from always to never were prepared to assess how teachers teach the pre, while and post reading stages. In scoring a point 5 was assigned for "always"4 represented "usually", 3 stood for "sometimes" 2 represented for "rarely" and 1 assigned for "never". The questionnaire was prepared based on literature adapted from Atkins et al (1996) \&Debritu etal.(2015) and given to three of my colleagues specialized in teaching English as a foreign language for comment, and I modified the questions based on the given comments. The pilot test was carried out in Azezo preparatory school by distributing the items to 30 grade twelve students and the reliability was calculated using cronbach alpha and found 0.82 which is greater than the minimum compromise value 0.75(Hinton, McMurray, \&Brownlow, 2014).

\section{DATA ANALYSIS AND THE FINDINGS}

Responses on Pre-reading Stage Practices
e-ISSN: 2249-4642, p-ISSN: 2454-4671

\section{Observation}

To assess what actually happens in the classroom during the teaching of reading skill, the researcher conducted observations. Inorder to triangulateand integrate data, students' questionnaire was again used as observation check list. This was intended to receive data about how teachers practice the three stages of reading. Six English teachers were selected and each of them was observed four times. Hence, the researcher carried out a total of twenty four observation sessions when the teaching of reading skill was going on.

\section{Interview}

Structured and semi structured questions were prepared and asked to the head of the English language department. He was selected purposely because the head worked as a supervisorin the school and could provide information about the reading practices in the classroom.

\section{Method of Data Analysis}

Once the data was collected, both quantitative and qualitative data analysis methods were used. Thus the data gathered through close ended questionnaire of students was analyzed using percentages and mean values with the integration of observation results which was analyzed using percentages. The data collected from interview was analyzed qualitatively. 
Table 1 : Students’ Response on Pre reading Items\&Classroom Observation Results

\begin{tabular}{|c|c|c|c|c|c|c|c|c|c|c|c|c|c|c|c|c|c|}
\hline \multirow[t]{3}{*}{ No } & \multirow{3}{*}{$\begin{array}{l}\text { Item } \\
\text { Pre reading Practices } \\
\text { The English teacher: }\end{array}$} & \multicolumn{14}{|c|}{ Number of respondents } & & \\
\hline & & \multicolumn{2}{|c|}{ Never(1) } & \multicolumn{2}{|c|}{ Rarely(2) } & \multicolumn{3}{|c|}{ Sometimes(3) } & \multicolumn{2}{|c|}{ Usually(4) } & \multicolumn{2}{|c|}{ Always(5) } & \multicolumn{2}{|c|}{ Total } & \multirow[t]{2}{*}{ Mean } & \multirow{8}{*}{ 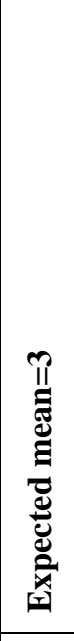 } & \\
\hline & & No & $\%$ & No & $\%$ & No & $\%$ & & No & $\%$ & No & $\%$ & No & $\%$ & & & \\
\hline 1 & $\begin{array}{l}\text { asks some general questions about the students } \\
\text { back ground knowledge related to the reading text before } \\
\text { they read it }\end{array}$ & 45 & 14.3 & 151 & 48.1 & 106 & 33.8 & & 8 & 2.5 & 4 & 1.3 & 314 & 100 & 2.2 & & \\
\hline 2 & teaches some key or difficult vocabulary words before reading & 37 & 11.8 & 141 & 44.9 & 120 & 38.2 & & 10 & 3.2 & 6 & 1.9 & 314 & 100 & 2.4 & & \\
\hline 3 & motivates or relaxes students to arouse interest and curiosity & 73 & 23.2 & 176 & 56.1 & 60 & 19.1 & & 3 & 1 & 2 & 0.6 & 314 & 100 & 2.0 & & \\
\hline 4 & $\begin{array}{l}\text { makes students to look at the topic and visual supports like } \\
\text { pictures, charts and predict what the text is about }\end{array}$ & 67 & 21.3 & 81 & 25.8 & 143 & 45.5 & & 18 & 5.7 & 5 & 1.6 & 314 & 100 & 2.4 & & \\
\hline 5 & $\begin{array}{l}\text { engages students in pair or group discussion on pre reading } \\
\text { questions }\end{array}$ & 120 & 38.2 & 107 & 34 & 35 & 11.1 & & 38 & 12.1 & 14 & 4.5 & 314 & 100 & 2.11 & & \\
\hline \multirow[t]{2}{*}{6} & gives clear instruction and purpose to students & 137 & 43.6 & 69 & 22 & 86 & \multicolumn{2}{|c|}{27.4} & 18 & 5.7 & 4 & $\mathbf{1 . 3}$ & 314 & 100 & 2.0 & & \\
\hline & Grand Total & 80 & 25.5 & 121 & 38.5 & 92 & \multicolumn{2}{|c|}{29.3} & 16 & 5.1 & 5 & 1.6 & 314 & 100 & 2.2 & & \\
\hline \multicolumn{18}{|c|}{ Classroom Observation Results } \\
\hline \multirow[t]{3}{*}{ No } & \multicolumn{3}{|l|}{ 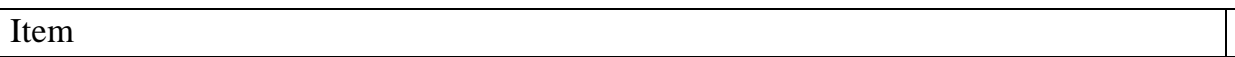 } & \multicolumn{14}{|c|}{ Classroom Observation Sessions } \\
\hline & \multicolumn{3}{|l|}{ Pre reading Practices } & \multicolumn{2}{|c|}{$\mathrm{CO} 1$} & \multicolumn{2}{|c|}{$\mathrm{CO} 2$} & \multicolumn{3}{|c|}{$\mathrm{CO} 3$} & \multicolumn{2}{|l|}{$\mathrm{CO} 4$} & \multicolumn{4}{|c|}{ Total Frequency } & \multirow[t]{2}{*}{ Total } \\
\hline & \multicolumn{3}{|l|}{ The English teacher: } & Yes & No & Yes & No & \multicolumn{2}{|c|}{ Yes } & No & Yes & No & Yes & $\%$ & No & $\%$ & \\
\hline 1 & \multicolumn{2}{|l|}{$\begin{array}{l}\text { asks some general questions about the students back ground knowledge } \\
\text { related to the reading text before they read it }\end{array}$} & & & 4 & 1 & 5 & 3 & & 3 & 2 & 4 & 8 & 33.3 & 16 & 66.7 & 24 \\
\hline 2 & teaches some key or difficult vocabulary words before reading & & & & 5 & 3 & 3 & 0 & & 6 & 2 & 4 & 6 & 25 & 18 & 75 & 24 \\
\hline 3 & motivates or relaxes students to arouse interest and curiosity & & & & 6 & 1 & 5 & 2 & & 4 & 1 & 5 & 4 & 16.6 & 20 & 83.3 & 24 \\
\hline 4 & $\begin{array}{l}\text { makes students to look at the topic and visual supports like pictures, } \\
\text { charts and predict what the text is about }\end{array}$ & & & & 6 & 0 & 6 & 1 & & 5 & 1 & 5 & 2 & 8.3 & 22 & 91.7 & 24 \\
\hline 5 & engages students in pair or group discussion on pre reading questions & & & & 5 & 2 & 4 & 3 & & 3 & 2 & 4 & 8 & 33.3 & 16 & 66.7 & 24 \\
\hline 6 & gives clear instruction and purpose to students & & & & 4 & 2 & 4 & 2 & & 4 & 1 & 5 & 7 & 29.2 & 17 & 70.8 & 24 \\
\hline & frequency total & & & & & & & & & & & & 6 & 25 & 18 & 75 & \\
\hline
\end{tabular}

Key: $\mathrm{CO} 1=$ Classroom Observation one, $\quad \mathrm{CO} 2=$ Classroom Observation two $\quad \mathrm{CO} 3=\mathrm{Classroom}$ Observation three, $\mathrm{CO} 4=\mathrm{Classroom}$ Observation four 
(IJRSSH) 2020, Vol. No. 10, Issue No. II, Apr-Jun

As indicated in item 1 of table one above, 45 (14.3\%) students responded that teachers never ask some questions about the students' background knowledge. Whereas $151(48.1 \%)$ replied that teachers rarely ask about their background knowledge related to the reading passage and 106(33.8\%) teachers sometimes ask questions about students background knowledge in relation to the reading text. The mean value of this item is (2.2) showing that most teachers ask rarely about the background knowledge of students.

The class room observation also indicated that $66.7 \%$ of the teachers did not ask back ground knowledge questions related to the passage. Atkins et al. (1996) underlined the need to ask some questions to understand students' background knowledge in teaching reading skill. In addition ,Debritu,et al. (2015)showed the importance of activating students prior knowledge to relate the new information to what students already know.

Regarding item 2 of table one, 37 (11.8\%) students replied that teachers never teach some key or unfamiliar vocabulary words before students read the passage and $141(44.9 \%)$ responses showed that teachers teach key or unfamiliar vocabulary rarely. However, $10(3.2 \%)$ and $6(1.9 \%)$ respondents portrayed that teachers teach some key or unfamiliar vocabulary 'usually' and 'always' respectively. The mean value (2.3) of the respondents portrayed that teachers teach key or unfamiliar vocabulary rarely. The classroom observation above showed that $18(75 \%)$ of the teachers never teach some key or unfamiliar vocabulary before students read the passage. Thus, it is possible to deduce from the above argument that most teachers never teach unfamiliar words before teaching reading .However,Atkins et,al .(1996)indicated the importance of teaching few key vocabularies which are central to the understanding of the whole passage in the prereading stage.

As it has been observed in item 3 of table one, 73 $(23.2 \%)$ of the students agreed that teachers are not in a tendency to motivate or relax students to arose interest and curiosity and $56.1 \%$ of the respondents replied that teachers motivate students to arise interest. In relation to this $0.6 \%$ respondents replied that teachers always
e-ISSN: 2249-4642, p-ISSN: 2454-4671

motivate students in teaching reading lessons. However, the mean value of the respondents (1.9) and observation check list $(83.3 \%)$ results depicted that most teachers did not motivate students to arise interest of students reading skill.Ur (1984) described the activity of motivation contribute to the interest and enjoyment of learning. Similarly, Abdu et, al.(2006:17) showed "motivation,that is wanting to read, is crucial."

As indicated in table one of item four, 67 (21.7\%)students response revealed that teachers never help students to look at the title and visual supports like pictures and charts before they read the text and 81 $(25.8 \%)$ of the respondents assured that teachers make students to look at visual supports rarely before reading the passage. While $45.5 \%$ respondents said teachers sometimes make students to look at visual supports and $5.7 \%$ and $1.6 \%$ of the respondents replied that teachers help students to look at visual supports 'usually' and 'always' respectively. The mean value (2.4) of the respondents inclined to the idea that teachers rarely make students to look at visual materials. The observation results of the researcher also revealed the questionnaire of students in that $91.7 \%$ of the teachers did not make students to look at visual materials before students read thepassage.Nevertheless, Debritu, et al. (2015)indicated that teachers should stimulate students' thinking by scanning the title,chapter headings, and other materials before reading a passage.

Item 5 of students response in table one, 120(38.2\%) indicated that teachers never form pair or group discussions on pre-reading questions. Besides,. $34 \%$ of them responded 'rarely' and $11.1 \%$ answered 'sometimes'. The remaining respondents $(12.1 \%$ usually and $4.5 \%$ always) replied that their teachers form pair or group discussions and make them discuss on pre reading questions. The mean value (2.1) shows teachers rarely make students discuss the pre reading questions. The observation results of the researcher confirmed that $33 \%$ of the teachers ordered their students to discuss on the pre reading questions whereas $66.7 \%$ of them never form groups to share ideas on pre reading questions.

In item 6 of table one, $43.6 \%$ of students reported that teachers never tell students clear instructions and purpose before reading is carried out. $22 \%$ respondents 


\section{(IJRSSH) 2020, Vol. No. 10, Issue No. II, Apr-Jun}

answered that teachers tell students clear instructions and purpose in rare cases and 27.4 said sometimes before reading the text. $5.7 \%$ of the respondents reported that teachers tell clear instructions and procedures usually while $1.3 \%$ assured that teachers always give clear instructions and procedures before they are allowed to read. Hence based on the mean value (2.0) and the frequency of the respondents, it is possible to deduce that teachers rarely tell clear instructions and procedures before reading the passage. The findings of class room observation revealed that
e-ISSN: 2249-4642, p-ISSN: 2454-4671

$70.8 \%$ of the teachers never tell clear instructions and procedures for students before they read the text. Contrary to this, Almaz, et al. (2012) emphasized that it is essential that students read with a purpose. The head of the department was also asked if teachers teach the pre-reading skill properly. He replied that most teachers never teach this stage based on the procedures stated on the text book and teachers' guide.Generally, the cumulative observation results of the pre reading practices of teachers indicated that $75 \%$ of the teachers could not implement the pre reading stage. 


\section{Responses on While-reading Stage Practices}

Table 2 : Students' Response on While- reading Items \& Classroom Observation Results

\begin{tabular}{|c|c|c|c|c|c|c|c|c|c|c|c|c|c|c|c|}
\hline \multirow[t]{3}{*}{ No } & \multirow{3}{*}{$\begin{array}{l}\text { Item } \\
\text { While Reading Practices } \\
\text { The English teacher: }\end{array}$} & \multicolumn{13}{|c|}{ Number of respondents } & \multirow{9}{*}{ 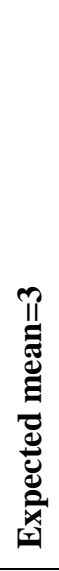 } \\
\hline & & \multicolumn{2}{|c|}{ Never(1) } & \multicolumn{2}{|c|}{ Rarely(2) } & \multicolumn{4}{|c|}{ Sometimes(3 Usually(4) } & \multicolumn{2}{|c|}{ Always(5) } & \multicolumn{2}{|c|}{ Total } & \multirow[t]{2}{*}{ Mean } & \\
\hline & & No & $\%$ & No & $\%$ & No & $\%$ & No & $\%$ & No & $\%$ & No & $\%$ & & \\
\hline 7 & $\begin{array}{l}\text { trains students to vary their reading speed according to their } \\
\text { purpose e.g how to skim, scan etc }\end{array}$ & 162 & 51.6 & 143 & 45.5 & 9 & 2.9 & $\mathbf{0}$ & $\mathbf{0}$ & $\mathbf{0}$ & $\mathbf{0}$ & 314 & 100 & 1.5 & \\
\hline 8 & instructs students to read silently and individually & 3 & 1 & 4 & 1.3 & 65 & 21 & 174 & 55.4 & 68 & 21.7 & 314 & 100 & 4.0 & \\
\hline 9 & $\begin{array}{l}\text { shows the students how to guess the meaning of new words } \\
\text { using contextual clues, word-building, antonym, synonym etc }\end{array}$ & 63 & 20.1 & 198 & 63.1 & 45 & 14.3 & 8 & 2.5 & $\mathbf{0}$ & $\mathbf{0}$ & 314 & 100 & 1.9 & \\
\hline 10 & makes students compare their answers in pairs or in groups & 24 & 7.7 & 52 & 16.6 & 153 & 48.7 & 83 & 26.4 & 2 & 0.6 & 314 & 100 & 2.9 & \\
\hline 11 & moves from group to group and support students & 36 & 11.5 & 78 & 24.8 & 135 & 43 & 41 & 13.1 & 24 & 7.6 & 314 & 100 & 2.8 & \\
\hline \multirow[t]{2}{*}{12} & $\begin{array}{l}\text { asks students to report their answers for a whole class } \\
\text { discussion }\end{array}$ & 2 & 0.6 & 5 & 1.6 & 29 & 9.3 & 260 & 82.8 & 18 & 5.7 & 314 & 100 & 3.9 & \\
\hline & Grand Total & 48 & 15.4 & 80 & 25.5 & 73 & 23.1 & 94 & 30 & 19 & 6 & 314 & 100 & 2.9 & \\
\hline
\end{tabular}

\begin{tabular}{|c|c|c|c|c|c|c|c|c|c|c|c|c|c|c|}
\hline \multicolumn{15}{|c|}{ Classroom Observation Results } \\
\hline \multirow[t]{3}{*}{ No } & Items & \multicolumn{12}{|c|}{ Classroom Observation Sessions } & \multirow{3}{*}{ Total } \\
\hline & While reading Practices & \multicolumn{2}{|l|}{$\mathrm{CO} 1$} & \multicolumn{2}{|l|}{$\mathrm{CO} 2$} & \multicolumn{2}{|l|}{$\mathrm{CO} 3$} & \multicolumn{2}{|l|}{$\mathrm{CO} 4$} & \multicolumn{4}{|c|}{ Total Frequency } & \\
\hline & The English teacher: & Yes & No & Yes & No & Yes & No & Yes & No & Yes & $\%$ & No & $\%$ & \\
\hline 7 & $\begin{array}{l}\text { teaches students to vary their reading speed according to their purpose } \\
\text { e.g how to skim, scan etc }\end{array}$ & 1 & 5 & 2 & 4 & 1 & 5 & 0 & 6 & 4 & 16.7 & 20 & 83.3 & 24 \\
\hline 8 & instructs students to read silently and individually & 5 & 1 & 4 & 2 & 3 & 3 & 5 & 1 & 17 & 70.8 & 7 & 29.1 & 24 \\
\hline 9 & $\begin{array}{l}\text { shows the students to guess the meaning of new words using } \\
\text { contextual clues, word-building, antonyms, synonyms etc }\end{array}$ & 2 & 4 & 3 & 3 & 1 & 5 & 2 & 4 & 8 & 33.3 & 16 & 66.7 & 24 \\
\hline 10 & makes students compare their answers in pairs or groups & 3 & 3 & 2 & 4 & 2 & 4 & 2 & 4 & 9 & 37.5 & 15 & 62.5 & 24 \\
\hline 11 & moves from group to group and support students & 0 & 6 & 2 & 4 & 3 & 3 & 2 & 4 & 7 & 29.2 & 17 & 70.8 & 24 \\
\hline 12 & asks students to report their answers for a whole class discussion & 4 & 2 & 3 & 3 & 4 & 2 & 2 & 4 & 13 & 54.2 & 11 & 45.8 & 24 \\
\hline & frequency total & & & & & & & & & 10 & 40.3 & 14 & 59.7 & \\
\hline
\end{tabular}

Key: $\mathrm{CO} 1=$ Classroom Observation one, $\quad \mathrm{CO} 2=$ Classroom Observation two

INTERNATIONAL JOURNAL OF RESEARCH IN SOCIAL SCIENCES AND HUMANITIES 
(IJRSSH) 2020, Vol. No. 10, Issue No. II, Apr-Jun

As pointed out in item 7 of table two, $51.6 \%$ of the students reported that teachers never train or assist them to vary their reading speed according to their purpose using different reading techniques like scanning and skimming. Related to this, 143 (45.5\%) of the students replied that their teachers rarely train them how to differ their reading speed based on their purpose. Very few of them $(2.9 \%)$ showed that teachers sometimes help them how to apply reading techniques e.g scanning, skimming. Moreover, the mean value (1.5) approached between the rating of never and rarely which implies that teachers almost do not train their students how to scan and skim during reading. The classroom observation also showed that most teachers didn't assist students how to apply different reading strategies. From these, we can understand that teachers do not provide emphasis about reading techniques that students use differently based on their purpose. According to Abdu, Andargachew and Abiy (2006) effective readers should be able to skim and scan the text.

As it has been observed in item 8 of table two, $1 \%$ of the respondents replied that teachers never tell them to read the passage individually and silently and $1.3 \%$ said that teachers rarely order to read the text silently and individually. $21 \%$ of the respondents said sometimes and $55.4 \%$ of the respondents depicted that teachers usually inform students to read the reading text silently and individually. Additionally, $21.7 \%$ of them replied that they are always told. The mean value(4) and the observation findings of the researcher revealed that most teachers (55.4\% usually, $21.7 \%$ always and $70.8 \%$ observation results) make students to read silently and individually. Regarding to this Atkins et al,(1996) indicated that students should read the text silently and individually for a detail understanding of a text and able to answer the questions.

According to table two of item nine, $20.1 \%$ of the respondents replied that teachers did not teach the students to guess the meaning of new words using guessing methods like context, word building, antonym, synonym etc. Besides, $63.1 \%$ said that teachers rarely show them word guessing methods, and $14.3 \%$ and $2.5 \%$ said sometimes and usually
e-ISSN: 2249-4642, p-ISSN: 2454-4671

respectively. More than half $(63.1 \%)$ respondents and mean value of (1.9) respondents confirmed that teachers rarely teach them how to guess the meaning of unfamiliar words. Similarly, the class room observation results of the researcher indicated that more $(66.7 \%)$ of the teachers never show them how to guess the meanings of words in the passage. Similar to the above finding, the observation results of the researcher revealed that $66.7 \%$ of the teachers never encourage students to guess the vocabulary words . However, Aebersold and Field,(1997) stated that readers should know how to use techniques to guess the meaning of unfamiliar words when they read. Therefore, teachers ought to have the knowledge of the techniques of guessing so as to assist students.

Students were asked whether teachers encourage students to compare their answer in pairs or in groups. Based on this, item 10 of table two with $7.7 \%$ response showed that teachers never encourage students to compare their answer in group or pairs to correct their mistake and/or learning each other and 16.6\% respondents reported that teachers assist students rarely in comparing or checking their answer one another after they did the questions related to the passage. Nevertheless, $153(48.7 \%)$ of the respondents claimed that teachers sometimes encourage students to compare and contrast their work in pair or in group and, $26.4 \%$ and $0.6 \%$ said usually and always respectively with regard to encouragement of comparing their answers among groups. The mean value (2.9) indicated that teachers sometimes encourage students to evaluate each other's work and about half (48.7\%) of the teachers applied this strategy. The observation result also portrayed that more than half $(62.5 \%)$ teachers never encourage students to compare their answers in pairs or in groups. According to Dubinand Bycina(19991)\&Nuttall (1996)showed that students should be in pairs or in small groups to discuss and compare their answers.

Responding to item eleven, $11.5 \%$ of the students answered that teachers did not move from group to group and support students in reading activities and $24.8 \%$ said teachers rarely round to groups to support their difficulties. However, $43 \%$ of the students said 
that teachers sometimes move from group to group to assist the problems students face. $13.1 \%$ and $7.6 \%$ of them replied usually and always respectively in response to teachers' support by moving from group to group in reading activities. The mean value (2.8) showed that teachers sometimes move from group to group and support the difficulties and the observation result depicted that more $(70.8 \%)$ of the teachers never round the class room to help students. This shows that most teachers spend their time by sitting till students finish their pair or group work.

Students were asked whether teachers ordered students to report their answers for a whole class discussion and $82.8 \%$ of them replied that teachers usually ask students to report their answers for a whole class discussion. $0.6 \%$ of the students said that teachers never give opportunities for students to present their answers in the class discussion. The class room observation investigated by the researcher also supported the above situation that more than half $(54.2 \%)$ of the teachers gave chances for students to present their answers for the whole class discussion. Regarding to this Atkinset al.(1996) stated that discussing the answers with the whole class helps students to enhance their understanding of the text.The supervisor responded about the teachers practice of the while reading stage was that the text book is very bulky having twelve units with forty eight passages. Therefore, teachers focus on the coverage of the text book and on the grammar topics. Due to this, teachers do not teach this and other reading stages thoroughly. Generally, the cumulative observation results of the while reading practices of teachers indicated that $59.7 \%$ of the teachers could not implement the while reading skill. 


\section{Responses on Post-reading Stage Activities}

Table 3 : Students' Response on Post- reading Items \& Classroom Observation Results

\begin{tabular}{|c|c|c|c|c|c|c|c|c|c|c|c|c|c|c|c|}
\hline \multirow[t]{3}{*}{ No } & \multirow{3}{*}{$\begin{array}{l}\text { Item } \\
\text { Post- reading Practices } \\
\text { The English teacher: }\end{array}$} & \multicolumn{13}{|c|}{ Number of respondents } & II \\
\hline & & \multicolumn{2}{|c|}{ Never(1) } & \multicolumn{2}{|c|}{$\operatorname{Rarely}(2)$} & \multicolumn{2}{|c|}{ Sometimes(3) } & \multicolumn{2}{|c|}{ Usually(4) } & \multicolumn{2}{|c|}{ Always(5) } & \multicolumn{2}{|c|}{ Total } & \multirow[t]{2}{*}{ Mean } & \multirow{4}{*}{ 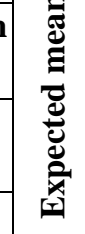 } \\
\hline & & № & $\%$ & No & $\%$ & No & $\%$ & No & $\%$ & No & \begin{tabular}{l|l} 
& $\%$
\end{tabular} & No & $\%$ & & \\
\hline 13 & $\begin{array}{l}\text { extends the reading activities and integrates with other language } \\
\text { skillseg. Writing, speaking }\end{array}$ & 153 & 48.7 & 13 & 4.1 & 132 & 42.0 & 12 & 3. & 4 & 1.3 & 314 & 100 & 2.0 & \\
\hline \multirow[t]{2}{*}{14} & gives appropriate and immediate feedback & 35 & 11.2 & 103 & 32.8 & 151 & 48.1 & 18 & 5. & 7 & 2.2 & 314 & 100 & 2.6 & \\
\hline & Grand Total & 94 & 29.9 & 58 & 18.4 & 142 & 45.2 & 15 & 4. & 6 & 1.8 & 314 & 100 & 2.3 & \\
\hline \multicolumn{16}{|c|}{ Classroom Observation Results } \\
\hline \multirow[t]{3}{*}{ No } & Item & \multicolumn{14}{|c|}{ Classroom Observation Sessions } \\
\hline & Post reading Practices & \multicolumn{2}{|c|}{$\mathrm{CO} 1$} & \multicolumn{2}{|c|}{$\mathrm{CO} 2$} & \multicolumn{2}{|l|}{$\mathrm{CO} 3$} & \multicolumn{2}{|l|}{$\mathrm{CO} 4$} & \multicolumn{4}{|c|}{ Total Frequency } & \multirow{2}{*}{\multicolumn{2}{|c|}{ Total }} \\
\hline & The English teacher: & Yes & No & Yes & No & Yes & No & Yes & No & Yes & $\%$ & No & $\%$ & & \\
\hline 13 & $\begin{array}{l}\text { extends the reading activities and integrates with other language } \\
\text { skills eg. writing, speaking }\end{array}$ & 1 & 5 & 0 & 6 & 0 & 6 & 1 & 5 & 2 & 8.3 & 22 & 91.7 & 24 & \\
\hline \multirow[t]{2}{*}{14} & gives appropriate and immediate feedback & 3 & 3 & 2 & 4 & 1 & 5 & 2 & 4 & 8 & \multirow{2}{*}{$\begin{array}{l}33.3 \\
20.8\end{array}$} & 16 & 66.7 & \multicolumn{2}{|l|}{24} \\
\hline & \multicolumn{9}{|l|}{ frequency total } & 5 & & 19 & 79.2 & & \\
\hline
\end{tabular}

Key: $\mathrm{CO} 1=$ Classroom Observation one $\mathrm{CO} 2=$ Classroom Observation two $\quad \mathrm{CO} 3=$ Classroom Observation threeCO4=Classroom Observation four 
(IJRSSH) 2020, Vol. No. 10, Issue No. II, Apr-Jun

According to Turner (1995) one language skill may not take place independently. It is usually integrated with the other or others. Throughout our daily lives we read and make comments; we listen and write. The language learning we do through listening should be connected with the language learning we do through speaking, reading and writing.Regarding to this in item 13, students were asked whether the teachers extend reading and integrate with other language skills .Thus, $(48.7 \%)$ of the respondents replied that teachers never extend the reading activities and integrates with other language skills and $(4.1 \%)$ replied rarely. The $2 \%$ ) respondents said that teachers sometimes integrate the reading activities with other language skills. The mean value (2.0) confirmed that teachers rarely extends the reading tasks and integrated with other skills even though $3.8 \%$ and $1.3 \%$ respondents reported usually and always respectively. Most of the teachers $(91.7 \%)$ never integrate reading activities with other skills as displayed in the above table of the researcher's observation check list. Yinager et al. (2005) states that it is advantageous to introduce all the four skills together because practicing one can support the development of the other. Therefore, it is worthy for English teachers to integrate one language skill with others when teaching reading.

As it has been observed in item 14 of table three, $11.2 \%$ of the respondents reported that teachers never give appropriate feedback when teaching reading and $32.8 \%$ said that teachers rarely give appropriate feedback. The $48.1 \%, 5.7 \%$ and $2.2 \%$ respondents said that teachers give appropriate feedback sometimes, usually and always respectively. More $(48.1 \%)$ of the respondents and the mean value (2.6) of the study indicated that teachers sometimes give appropriate feedback when teaching reading skill.The finding of the observation check list confirmed the above finding in that $66.7 \%$ of the teachers do not give immediate and appropriate feedback. The interview result of the supervisor showed that teachers don't give much emphasis in teaching this stage.Generally, the cumulative results of the post reading practices of teachers indicated that $79.2 \%$ of the teachers could not implement this reading skill.
e-ISSN: 2249-4642, p-ISSN: 2454-4671

With regard to this Underwood (1989) states whatever activities you choose to use, it is important to provide immediate feedback and Harmer (2001) states that teachers should have feedback session to see how students completed effectively. The teacher may ask students to compare their answers in pairs and then the class in general.

\section{CONCLUSION}

This study was conducted on the practice of teaching reading skill of grade twelve at Fasiledes Preparatory School.Based on the findings, it is possible to conclude that the degree of implementation of the three stages of reading skill in the classroom is relatively different. The mean value indicatesthat the pre reading stage is implemented rarely. The observation result also indicates that most teachers could not implement the pre reading activities in the classroom. Thewhile reading skill is sometimes practiced. It is better implemented Compared to the pre and post reading stages. When we see the practice of the post reading stage, the mean value portrays that teachers rarely implement the post reading activities in the classroom. The observation result is also the witness that most teachers don't properlyteach the post reading stage.

\section{RECOMMENDATIONS}

Teaching reading skill is the important instrument to augment the academic performance of students. However, the results of this study showed that teachers are less likely in implementing the three stages of the reading skills. Therefore the teaching methodology of the teachers should be improved. The concerned stakeholders like the government and nongovernmental organizations should give greater attention in boosting the skill, knowledge and attitude of the teachers. The government should devise the professional development strategies to enhance the performance of the teachers. The supervisors and education experts of Gondar city administration should provide need based trainings, rethinking mentoring and coaching schemes that facilitate better teaching- learning process is imperative to mitigate the problem. 
(IJRSSH) 2020, Vol. No. 10, Issue No. II, Apr-Jun

\section{LIMITATIONS AND DIRECTIONS FOR FUTURE RESEARCH}

Thepresentstudyisnotwithoutlimitations.First,itislimitedt oonly grade twelve preparatory school students in Fasiledes Preparatory school. Consequently, it isless likely to generalize theseresultsto otherpopulations.In this study the practice of the implementation of the three stages of teaching reading skill is assessed. However, other variables like the challenges teachers face during teaching reading skill and their influence onthe development of the reading skill of students are not studied. Hence,Iencouragefurtherstudieson a large and comprehensive setting of primary and secondary schools to see the implementation of the three stages of reading skills. I alsoencouragefutureresearcherstofind variables that hamper the development of reading skill of students andthe challenges teachers face in teaching the three stages of reading skills.

\section{ACKNOWLEDGEMENT}

Iwouldliketoexpressmyheartfeltgratitudeto English Language teachers and grade twelve students of Fasiledes Preparatory School for their cooperation in the process of data collection. Besides,my greatestindebtedness goes to Dr.Yoseph Mezgebu and Prof. Alexander Raju for their encouragement and support from the beginning to the end of the study.

\section{REFERENCE}

Abdu Mohammed, Andargachew Moges, Abiy Yigzaw. (2006). ELT methodology II: Distance program of Bahir Dar University English Department: Bahir Dar University.

Aebersold,J., \&Field,M. (1997). Fromreadertoreadingteacher:Issues and strategiesforsecondlanguageclassrooms. Cambridge: Cambridge University Press.

Albdour,W.M.(2015).

Thedifficultiesthatseventhgradestudentsfacein comprehensivereadingskillforEnglishcurricula.Journal of Education and Practice, 6 (27).
e-ISSN: 2249-4642, p-ISSN: 2454-4671

Almaz Baraki, Keedwell, A., Fenech, D., Vermeulen, E., Fergusen, J., Hare, P., Jones, s., \& Adaye, Y.(2012). Reading secondary teachers' booklet(module four). Addis Ababa, Ethiopia: Ministry of Education.

Atkins, J., HailomBanteyerga\& Nuru Mohammed.(1996). Skills development methodology (partII).AddisAbaba:AddisAbabaUniversityPress

Breen, M. (1989).Theevaluationcycleforlanguagelearningtask s:The secondlanguagecurriculum. Cambridge: Cambridge Universitypress.

Debritu Minayehu, Mengesha Bogale, Assefa Demis, Yechale Akalu. (2015). Reading skill: College of teachers education training module. Bahirdar: Amhara National Regional State Education Bureau.

Dereje Wondimeneh . ( 2008 ). An investigation of students' perception of motivational techniques teachers use for reading lesson( Unpublishedmaster's thesis). Addis Ababa:AddisAbabaUniversity.

Devine,L.(1981).Reading inhighschools. NewYork:CollierEducational Corporation.

Dubin,F., \&Bycina,D. (1991).Academicreadingand ESL/EFLteacher inCelce Maurciateaching Englishas foreignand second language $\left(2^{\text {nd }} e d\right.$. ).Boston:HeinleandHeinlepublishers.

Getachew Asrat. (1996). The Teaching of reading in government high schools in Addis Ababa: A descriptive Study (Unpublished master's thesis).Addis Ababa: Addis Ababa University.

Harmer, J. (2001). The practice of English Language teaching. London: Long man.

Hinton, P.R.,McMurray, I.,\&Brownlow, C.(2014). SPSSexplained ( $2^{\text {nd }}$ ed.). NewYork: Routledge.

Khand,Z. (2004).Teaching reading skills: problems and suggestions. Retrieved 
fromhttp://bzu-edu.pk/jrlanguages/vol5\%20-2004/ziauddin\%20 khand-4-pdf

Krashen, S., \& Terrell, T.(1983). The natural approach in the class room. Hayward: CA Alemany press.

Kucukoglu, H. (.2013). Improving reading skillsthrough effective reading strategies. Procedia - Social and Behavioral Sciences, 70; 709 - 714 .

Mesfin Derash. (2008). The practice of teaching reading in English at First Cycle Primary Schools:Grade Four in focus (Unpublishedmaster's thesis). Addis Ababa:AddisAbabaUniversity.

Nunan, D.(1988). The learnercenteredcurriculum. Cambridge:CambridgeUniv ersitypress.

Nuttall, $\quad$ C.(1996).Teachingreadingskillsin aforeignlanguage.Oxford:Heinemann.

Paulos Gadebo. (2015).Analysisofreadingactivities:ThecaseofGrade 11TextBook (Unpublishedmaster's thesis). Addis Ababa:AddisAbabaUniversity.

Scotts, \& windy. (1994). Teaching English to children. Cambridge : Cambridge University Press.

Turner, K. (1995). Listening in a foreign language. Great Britain: Oakdale Printing co LTD.

Underwood, M. (1989). Teaching listening. London: Longman.

Ur, P. (1984) .Teaching listening comprehension.Cambridge: Cambridge UniversityPress Yinager TekleSillassie, Asres Nigus, \& Kassie Shifere. (2005). Listening skills module (flee 105): Distance Education Program. Bahirdar: Bahirdar University. 